\title{
KEPATUHAN MINUM OBAT PADA PASIEN ULKUS DIABETIKUM DI PROVINSI DAERAH ISTIMEWA YOGYAKARTA: MIX METHODE
}

\author{
Amanda Marselin ${ }^{1, *}$, Fajar Agung Dwi Hartanto', dan Maria Putri Sari Utami²
}

\author{
'Program Studi S1 Farmasi STIKES Notokusumo Yogyakarta \\ ${ }^{2}$ Program Studi D3 Keperawatan STIKES Notokusumo Yogyakarta
}

Info Article

Submitted :

20 Mei 2021

\section{Revised :}

23 Juli 2021

Accepted :

28 Juli 2021

\section{Corresponding Author :}

Amanda Marselin

\section{Email :}

amandamarselin@gmail.com

\section{ABSTRAK}

Provinsi D.I. Yogyakarta merupakan salah satu wilayah dengan prevalensi tertinggi diabetes mellitus (DM) di Indonesia. Salah satu komplikasi yang banyak dialami pasien DM ialah terjadinya ulkus diabetik pada kaki. Dengan adanya peningkatan prevalensi diabetes menyebabkan adanya peningkatan kasus amputasi kaki karena komplikasinya. Pasien DM membutuhkan terapi farmakologis berupa obat antidiabetes oral yang harus dikonsumsi dalam jangka waktu yang lama. Kepatuhan pasien pada semua aspek dalam tata laksana terapi DM sangat penting untuk mencapai hasil terapi yang optimal, terlebih jika pasien mengalami komplikasi ulkus diabetik. Terapi farmakologi memiliki peranan untuk menjaga kadar gula darah tetap terkontrol selama pasien menjalani perawatan luka sehingga tahapan dan proses penyembuhan luka yang dialami pasien bisa berjalan optimal. Penelitian ini bertujuan mengetahui tingkat kepatuhan minum obat pada pasien ulkus diabetikum. Jenis penelitian termasuk penelitian deskriptif analitik dengan pendekatan mix method. Tempat penelitian pada lima klinik perawatan luka di wilayah DIY. Jumlah responden 31 orang dengan teknik accidental sampling. Pengumpulan data dilakukan menggunakan kuesioner kepatuhan obat. Berdasarkan karakteristik responden diketahui $51.6 \%$ berjenis kelamin perempuan dengan rentang usia terbanyak antara 51-60 tahun (51.6\%). Hasil analisis deskriptif menunjukkan bahwa tingkat kepatuhan minum obat pasien DM dengan ulkus diabetikum di wilayah DIY sebesar $45,2 \%$. Tingkat kepatuhan minum obat pasien ulkus diabetikum di Provinsi DIY masih tergolong kurang. Hal tersebut menunjukkan perlu dilakukan intervensi mengenai kepatuhan minum obat untuk meminimalkan komplikasi lainnya.

Kata kunci: Diabetes Mellitus, Ulkus Diabetik, Kepatuhan Minum Obat.

Access this article

\section{ABSTRACT}

Yogyakarta Special Region province is one of the regions with the highest prevalence of diabetes mellitus (DM) in Indonesia. The complication that is experienced by many DM patients is the occurrence of diabetic ulcers on the legs. The rising prevalence of diabetes leads to an increase in cases of leg amputation due to complications. DM patients need pharmacological therapy in the 


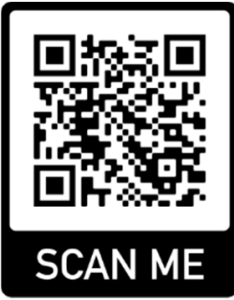

form of oral antidiabetic drugs that must be taken for a long period of time. Patient adherence to all aspects of DM therapy management is essential to achieve optimal therapeutic outcomes, especially if the patient has complications of diabetic ulcers. Pharmacological therapy has a role to keep blood sugar levels controlled during the patient's wound treatment so that the stages and process of wound healing experienced by the patient can be implemented optimally. This study aims to determine the level of drugs taking adherence of diabetic ulcer patients. This research is descriptive analytical research with a mix method approach. The research site at five wound care clinics in the Yogyakarta special Region. The number of respondents is 31 people with accidental sampling techniques. Data collection is carried out using a drug compliance questionnaire. Based on the characteristics of respondents, it is identified that $51.6 \%$ is Female with the most age range between 51-60 years (51.6\%). Descriptive analysis showed that the compliance rate of DM patients with diabetic ulcers in the Yogyakarta Special Region is $45.2 \%$. The level of drugs taking adherence of diabetic ulcer patients in the Province of Yogyakarta Special Region is still relatively low. This indicates that interventions need to be made regarding the adherence of taking the drug to minimize other complications.

Keywords: Diabetes Mellitus, Diabetic Ulcer, Drug Adherence.

\section{PENDAHULUAN}

Berdasarkan hasil dari Riset Kesehatan Dasar (Riskerdas) pada tahun 2013 diketahui bahwa salah satu penyakit tidak menular dengan tingkat prevalensi yang tinggi di Indonesia adalah diabetes mellitus. Diabetes mellitus (DM) adalah salah satu penyakit kronis yang terjadi karena adanya resistensi insulin yang menyebabkan kadar gula dalam darah meningkat (Al Goblas and Khan, 2014). Provinsi D.I. Yogyakarta merupakan salah satu wilayah dengan prevalensi tertinggi DM di Indonesia. Di Indonesia tingkat prevalensi DM yang terdiagnosis oleh dokter sebesar 2,1\%, di mana tingkat prevalensi yang paling tinggi berada di Provinsi D.I. Yogyakarta sebesar 2,6\%. Hal tersebut perlu mendapatkan perhatian terkait penanganan manajemen terapi pasien DM yang ada di Yogyakarta (Kementerian Kesehatan RI, 2013).

Salah satu komplikasi yang banyak dialami pasien diabetes mellitus ialah terjadinya ulkus diabetik pada kaki (diabetic foot ulcer). Kaki diabetik dapat didefinisikan sebagai adanya infeksi, ulserasi atau penghancuran jaringan dalam, yang berhubungan dengan kelainan neurologis dan adanya berbagai penyakit pembuluh darah perifer di tungkai bawah. Kaki diabetik dan berbagai komplikasi pada tungkai bawah yang parah dan kronis dapat mempengaruhi 40 hingga 60 juta orang yang mengalami diabetes secara global (IDF, 2019). Kaki diabetes yang tidak dilakukan perawatan dengan baik akan mudah mengalamai luka, dan cepat berkembang menjadi ulkus gangren bila tidak dirawat dengan cara 
yang benar (Soegondo, 2015). Berdasarkan diagnosis dari dokter, data prevalensi diabetes di Indoesia meningkat $2 \%$ dari tahun 2013 sampai 2018, sedangkan di Provinsi D.I. Yogyakarta sendiri terjadi peningkatan $1,3 \%$ di rentang waktu yang sama (Kementerian Kesehatan Rl, 2018). Dengan adanya peningkatan prevalensi diabetes menyebabkan adanya peningkatan kasus amputasi kaki karena komplikasinya. Dari hasil studi epidemiologi diketahui lebih dari satu juta tindakan amputasi dilakukan pada penyandang diabetes per tahunnya, yang menggambarkan setiap 30 detik ada kasus amputasi kaki karena kejadian diabetik di seluruh dunia (Lesmana, 2010).

Penderita DM sering mengalami keluhan yang disebabkan berbagai faktor resiko seperti karakteristik individu yang meliputi jenis kelamin, umur, tingkat pendidikan, jenis pekerjaan, pendapatan, jumlah anggota keluarga, riwayat penyakit. Selain itu juga dapat juga dipengaruhi oleh adanya faktor penanganan yang meliputi diet, aktivitas fisik, terapi obat, dan pemantauan glukosa darah (Trisnawati dan Setyorogo, 2013). Pasien DM membutuhkan terapi farmakologis berupa obat antidiabetes oral yang harus dikonsumsi dalam jangka waktu yang lama. Kepatuhan pasien DM dalam mengkonsumsi obat antidiabetes oral sangat diperlukan untuk mencapai keberhasilan pengobatan jangka panjang (Fitriani et al., 2015). Ketidakpatuhan dalam minum obat secara rutin dapat mengakibatkan terjadinya komplikasi, risiko rawat inap, dan biaya yang lebih tinggi (Srikartika et al., 2015). Kepatuhan pasien pada semua aspek dalam tata laksana terapi DM sangat penting untuk mencapai hasil terapi yang optimal, terlebih jika pasien mengalami komplikasi ulkus diabetik. Kepatuhan pasien dalam minum obat sangat penting bagi pasien DM dengan ulkus diabetik. Terapi farmakologi memiliki peranan penting untuk menjaga kadar gula darah tetap terkontrol selama pasien menjalani perawatan luka sehingga tahapan dan proses penyembuhan luka yang dialami pasien bisa berjalan optimal.

Berdasarkan uraian yang telah dipaparkan, rumusan masalah dalam penelitian ini yaitu bagaimana tingkat kepatuhan minum obat pada pasien ulkus diabetikum. Tujuan penelitian ini untuk mengetahui tingkat kepatuhan minum obat pada pasien ulkus diabetikum. Manfaat penelitian ini sebagai bahan pertimbangan dan masukan bagi pasien ulkus diabetikum agar mengetahui dampak yang diakibatkan karena ketidakpatuhan minum obat. Selain itu juga bermanfaat dalam memberikan pengetahuan dan wawasan masyarakat dalam kepatuhan minum obat terutama pada pasien dengan penyakit kronis yang membutuhkan pengobatan jangka panjang.

\section{METODE PENELITIAN}

Penelitian ini merupakan penelitian deskriptif analitik. Analisis data dilakukan secara kuantitatif dan kualititatif. Data kuantitatif adalah data untuk mengetahui pola penggunaan obat berdasarkan usia, jenis kelamin, dan tingkat kepatuhan minum obat. Data kualitatif digunakan untuk mengkaji ketepatan penggunaan obat berdasarkan kriteria penggunaan obat yang telah ditetapkan. Data kualitatif diperoleh dengan teknik wawancara. 
Penelitian ini dilakukan di 5 klinik perawatan luka di Yogyakarta. Klinik perawatan luka yang digunakan merupakan tempat praktek klinik mandiri perawat. Lima klinik perawatan luka ini dipilih dari total 10 klinik perawatan luka yang ada dan memenuhi jumlah responden sesuai dengan kriteria inklusi dalam penelitian ini. Pemilihan lima klinik perawatan luka tersebut didasarkan pada ketersediaan jumlah pasien di masingmasing klinik perawatan luka yang sesuai dengan kriteria inklusi serta kesediaan dari klinik perawatan luka tersebut sebagai mitra tempat penelitian selama masa periode waktu pengambilan data dengan keterbatasan dalam masa pandemi covid19.

Teknik pengambilan sampel dilakukan dengan teknik accidental sampling. Penelitian dilakukan selama bulan Maret-Juni 2020 dan diperoleh responden sebanyak 31 pasien dengan kriteria inklusi adalah pasien DM, menggunakan obat antidiabetes, sedang menjalani perawatan luka ulkus diabetik dan bersedia menjadi responden. Instrumen yang digunakan dalam penelitian ini adalah kuesioner MMAS-8 (Morisky Medication Adherence Scale) yang merupakan skala kuesioner dengan butir pertanyaan sebanyak 8 butir menyangkut dengan kepatuhan minum obat. Kepatuhan minum obat dikategorikan dalam 2 penilaian yaitu patuh dengan nilai $\geq 6$ dan tidak patuh dengan nilai $<6$. Penelitian ini sudah dinyatakan layak etik oleh Komite Etik Penelitian Kesehatan STIKES Surya Global Yogyakarta dengan surat etik nomor 1.31//KEPK/SG/III/2020.

\section{HASIL DAN PEMBAHASAN}

Responden yang menjadi subyek dalam penelitian ini berjumlah 31 orang yang berasal dari lima klinik perawatan luka di Yogyakarta. Karakteristik pasien pada penelitian ini sebagian besar berjenis kelamin perempuan sebanyak 51,6\%, sedangkan berdasarkan faktor usia paling banyak pasien berada pada rentang usia 51-60 tahun (51,6\%). Hasil penelitian untuk faktor kepatuhan minum obat menunjukkan bahwa $45.2 \%$ pasien patuh dalam menggunakan obat. $\mathrm{Hal}$ ini menunjukkan tidak semua pasien DM dengan ulkus diabetikum taat dan patuh dalam menjalani terapi pengobatan secara rutin. 
Tabel 1. Karateristik Responden Berdasarkan Jenis Kelamin, Usia, Lama Menderita dan Tingkat Kepatuhan Obat.

\begin{tabular}{ccc}
\hline Variabel & Jumlah & Persentase \\
\hline Jenis Kelamin & & \\
Laki-laki & 15 & 48.4 \\
Perempuan & 16 & 51.6 \\
\hline Usia & & \\
30-40 tahun & 3 & 9.7 \\
$41-50$ tahun & 5 & 16.1 \\
$51-60$ tahun & 16 & 51.6 \\
$>60$ tahun & 7 & 22.6 \\
\hline Tingkat Kepatuhan Obat & & \\
Patuh & 14 & 45.2 \\
Tidak patuh & 17 & 54.8 \\
\hline
\end{tabular}

Jumlah pasien DM dengan jenis kelamin perempuan lebih banyak dibandingkan laki-laki, sesuai dengan hasil Riset Kesehatan Dasar (Riskesdas) yang menyatakan bahwa prevalensi DM dengan gejala dan diagnosis dokter mengalami peningkatan pada perempuan sesuai bertambahnya usia, namun mengalami penurunan mulai usia $\geq 65$ tahun (Kementerian Kesehatan RI, 2013). Hasil penelitian ini sesuai dengan hasil Riskesdas tersebut menunjukkan bahwa responden penelitian paling banyak berjenis kelamin perempuan.

Penelitian lain yang pernah dilakukan oleh Nazriati (2018) tentang pengetahuan dan kepatuhan minum obat pada pasien DM di Puskesmas Mandau Kabupaten Bengkalis juga menunjukkan hasil bahwa karakteristik responden paling banyak berjenis kelamin perempuan sebesar $62,5 \%$, dengan data berdasarkan hasil wawancara bahwa pasien perempuan mengaku kurang melakukan aktivitas fisik. Faktor lain adalah kejadian DM gestasional yang dapat terjadi pada ibu hamil dan berlanjut menjadi DM tipe 2 sehingga jumlah penderita DM lebih banyak terjadi pada jenis kelamin perempuan dibandingkan laki-laki.

Pasien dengan jenis kelamin laki-laki memiliki tingkat kepatuhan obat lebih rendah dibandingkan dengan pasien perempuan. Hal ini disebabkan pasien lakilaki akan cenderung mengabaikan kepatuhan dibandingkan perempuan. Hasil penelitian yang pernah dilakukan pada pasien DM di Puskesmas wilayah DIY menunjukkan tingkat kepatuhan obat pada pasien perempuan sebesar $46,7 \%$ lebih tinggi dibanding pasien laki-laki yang hanya sebesar 35,5\% (Rasdianah et al., 2016). Penelitian lain yang pernah dilakukan pada pasien DM pada tahun 2019 di Puskesmas Pancoran Mas Depok menunjukkan bahwa tingkat kepatuhan obat yang rendah pada pasien laki-laki dibandingkan perempuan (Jasmine et al., 2020).

Pada umumnya perempuan lebih memperhatikan akan kondisi kesehatannya, sedangkan laki-laki sering tidak peduli dengan kesehatan dan kondisi tubuh mereka, walaupun sudah terkena penyakit tertentu tetapi mereka masih enggan untuk memeriksakan kesehatannya secara teratur (Waluyo dan 
Budhi, 2013). Perbedaan gender mempengaruhi perilaku kesehatan dari laki -laki dan perempuan. Menurut White, gender adalah gambaran pola perilaku dari laki-laki atau perempuan yang diakui dalam masyarakat (Rosmalia dan Yustiana, 2017). Perbedaan itulah yang membuat perempuan lebih peduli dengan kesehatannya dibandingkan dengan lakilaki sehingga perempuan lebih patuh terhadap pengobatan DM dibandingkan laki-laki. Hal itu sesuai dengan hasil penelitian ini dimana ditemukan tingkat kepatuhan obat pada pasien laki-laki masih rendah.

Tingkat kepatuhan obat pada lakilaki cenderung lebih rendah dibandingkan perempuan didasari beberapa faktor meliputi kesadaran mengenai kondisi penyakit, dukungan keluarga, dan biaya perawatan (Kumar, et al, 2021). Pasien perempuan akan lebih menyadari kondisi penyakit yang dialami daripada laki-laki yang cenderung menganggap hal yang biasa saja. Dukungan keluarga terhadap pasien perempuan akan lebih besar daripada laki-laki karena perempuan lebih lemah dari kondisi fisiknya daripada lakilaki. Selain itu pasien laki-laki kurang memahami arti pentingnya perawatan dan pencegahan luka dari segi biaya yang dikeluarkan.

Semakin lama durasi penyakit dengan frekuensi dan regimen obat yang semakin kompleks maka semakin buruk tingkat kepatuhan minum obat seseorang. Hal ini dikuatkan dengan penelitian yang dilakukan di Puskesmas Pancoran Mas Depok bahwa tidak ada perbedaan tingkat kepatuhan pada pasien yang menerima monoterapi atau kombinasi. Kedua kelompok tersebut memiliki tingkat kepatuhan obat yang rendah (Jasmine et al., 2020). Pasien DM pada penelitian ini mengalami komplikasi ulkus diabetikum yang menunjukkan bahwa pasien tidak hanya menggunakan obat untuk terapi DM jangka panjang, namun juga disertai terapi untuk ulkus diabetikum. Hal tersebut akan menambah kompleks frekuensi dan regimen pengobatan pasien dan menyebabkan tingkat kepatuhan obat yang rendah.

Faktor kesibukan dalam menjalankan aktivitas sehari-hari merupakan penyebab ketidakpatuhan obat pada pasien dalam penelitian ini. Hal ini ditunjukkan dari hasil wawancara mendalam dengan 11 pasien ada sejumlah 4 pasien yang melaporkan bahwa aktivitas sehari-hari membuat lupa untuk minum obat. Pernyataan salah satu pasien tersebut adalah "sibuk ke sawah sampai maghrib tidak minum obat, terus gulanya naik", ada juga pasien lain yang menyatakan "sering kalau ketiduran jadi lupa minum obat".

Laki-laki cenderung tidak patuh karena banyaknya kegiatan terutama pada usia produktif sehingga sering mengabaikan pengobatan yang harus dilakukan secara rutin. (Jasmine et al., 2020). Pada usia produktif laki-laki akan selalu berupaya melakukan berbagai aktivitas yang berkaitan dengan pekerjaan sehari-hari maupun sebatas hobi. Hobi laki-laki yang lebih mengutamakan aspek fisik seringkali mengakibatkan tingkat penyakit menjadi lebih berat tanpa diketahui. Hal ini yang juga menyebabkan laki-laki cenderung lebih rendah tingkat kepatuhan obatnya daripada perempuan.

Pasien yang tidak bekerja lebih patuh dalam menggunakan obat karena tidak banyak memiliki kesibukan sehingga 
dapat pergi mengambil obat, mengingat waktu minum obat dan menggunakan obat lebih banyak waktu luang (Diantari dan Sutarga, 2019). Pekerjaan merupakan salah satu dari aktivitas sehari-hari yang rutin dilakukan oleh pasien. Hal ini sesuai pada hasil penelitian ini berdasarkan wawancara menunjukkan bahwa kesibukan melakukan aktivitas sehari-hari merupakan faktor yang menyebabkan pasien lupa dan tidak patuh dalam menggunakan obat.

\section{KESIMPULAN}

Kesimpulan dari hasil penelitian ini adalah tingkat kepatuhan obat pasien DM dengan ulkus diabetikum sebesar 45,2\%. Kesibukan dalam melakukan aktivitas sehari-hari merupakan penyebab ketidakpatuhan obat pada pasien DM dengan ulkus diabetikum.

\section{UCAPAN TERIMA KASIH}

Peneliti mengucapkan terima kasih kepada pengelola klinik rawat luka di wilayah DIY yang telah memberikan ijin dan kesempatan kepada peneliti untuk melakukan penelitian. Terima kasih juga diucapkan kepada Kemenristek/BRIN yang telah memberikan bantuan dana sehingga penelitian ini dapat berjalan dengan baik.

\section{DAFTAR PUSTAKA}

Al Goblas, A. A. M. and Khan, M, (2014). Mechanism Linking Diabetes Mellitus and Obesity. Dove Press Journal Diabetes Methabolic Syndrome and Obesity: Targets and Therapy. 7(7): 587 $-591$.

Diantari, I.A.P. dan Sutarga, I.M. 2019. Kepatuhan Minum Obat Pada Pasien Diabetes Mellitus Tipe 2 Di Wilayah Kerja Puskesmas Tabanan II Tahun 2019. Archive of Community Helath, 6(2):4050.
https://doi.org/10.24843/ACH.2019.v06. i02.p04

Fitriani R, Masruhim MA, Rahmawati D. (2015). Analisa Tingkat Kepatuhan Penggunaan Terapi Obat Oral Antidiabetik (OAD) Pada Pasien Diabetes Mellitus Di Instalasi RSUD. A.W Sjahranie. Prosiding Seminar Nasional Kefarmasian Ke-2. https://prosiding.farmasi.unmul.ac.id/in dex.php/mpc/article/view/40

International Diabetes Federation. (2019). IDF Diabetes Atlas Ninth Edition 2019. Dunia : IDF. Dikutip dari https://diabetesatlas.org/en/ pada tanggal 1 April 2021.

Jasmine, N.S., Wahyuningsih, S. dan Thadeus, M.S. 2020. Analisis Faktor Tingkat Kepatuhan Minum Obat Pasien Diabetes Melitus di Puskesmas Pancoran Mas Periode Maret-April 2019. Jurnal Manajemen Kesehatan Indonesia, 8(1): 61-66,

https://doi.org/10.14710/jmki.8.1.2020. 61-66

Kemenkes RI. (2013). Riset Kesehatan Dasar: RISKESDAS. Jakarta: Balitbang Kemenkes RI.

Kemenkes, RI. 2018. Infodatin Diabetes. Jakarta: Pusat Data dan Informasi Kemenkes RI.

Kumar, H, Abdulla, R.A \& Lalwani, H. 2021. Medication Adherence among Type 2 Diabetes Mellitus Patients: A Cross Sectional Study in Rural Karnataka (India), Athens Journal of Health \& Medical Sciences, 8(2): 107-118.

Lesmana, R. (2010). Ulkus Diabetikum, Medika Jurnal Kedokteran Indonesia, 36(5):318321.

http://isjd.pdii.lipi.go.id/file_download/ 36510318321_0126-0901.pdf

Nazriati, E., Pratiwi, D., dan Restuastuti, T. 2018. Pengetahuan Pasien Diabetes Mellitus Tipe 2 Dan Hubungannya Dengan Kepatuhan Minum Obat di Puskesmas Mandau Kabupaten Bengkalis. Majalah Kedokteran Andalas, 41(2):59-68. https://doi.org/10.25077/mka.v41.i2.p5 9-68.2018

Rasdianah, N., Martodiharjo, S., Andayani, T. M., dan Hakim, L. (2016). Gambaran Kepatuhan Pengobatan Pasien Diabetes 
Melitus Tipe 2 di Puskesmas Daerah Istimewa Yogyakarta The Description of Medication Adherence for Patients of Diabetes Mellitus Type 2 in Public Health Center Yogyakarta. 5(4). https://doi.org/10.15416/ijcp.2016.5.4.2 49

Rosmalia, D dan Yustiana S. 2017. Bahan Ajar Keperawatan Gigi: Sosiologi Kesehatan. Jakarta: Pusat Pendidikan Sumber Daya Manusia Kesehatan, Badan Pengembangan dan Pemebrdayaan Sumber Daya Manusia Kesehatan. Edisi Tahun 2017.

Soegondo, S. (2015). Penatalaksanaan Diabetes Mellitus Terpadu. Jakarta: Balai Penerbit
Srikartika, V. M., Cahya, A. D., Suci, R., \& Hardiati, W. (2016). Analisis Faktor Yang Memengaruhi Kepatuhan Penggunaan Obat Pasien Diabetes Melitus Tipe 2, Jurnal Manajemen dan Pelayanan Farmasi, 6(3): 205-212.

Trisnawati, S. K., \& Setyorogo, S. (2013). Faktor Risiko Kejadian Diabetes Melitus Tipe II Di Puskesmas Kecamatan Cengkareng Jakarta Barat Tahun 2012, Jurnal IImiah Kesehatan, 5(1): 6-11.

Waluyo, S dan Budhi M.P. 2013. Cek Kesehatan Anda: Pria Usia 50 Tahun. Jakarta: PT Elex Media Komputindo. 